\title{
THERMAL CHARACTERISTICS OF NEW BUILDING MATERIALS AND THEIR EFFECT UPON THE ENERGY EFFICIENCY
}

\author{
J. Ekmanis, V. Zebergs, N. Zeltins \\ Institute of Physical Energetics \\ 21 Aizkraukles Str., Riga, LV-1006, LATVIA \\ V. Vrublevskis \\ Riga Technical University \\ 1 Kalku Str., Riga, LV-1050, LATVIA
}

\begin{abstract}
The paper formulates the role of thermal inertia of the building materials in the energy supply of buildings and in solution of the energy efficiency problems. The evolution of construction entails the application of new building materials as well as of glazed surfaces in the envelopes of buildings. An analysis is made of the influence of the thermal resistance of building materials and their heat capacity on the thermal inertia indicators of buildings. An inertia scale of buildings has been developed for the choice of the heat supply capacities of buildings at low outdoor temperatures under extreme conditions of the Latvian climate. The ratio of the ventilation capacities has been analysed in the total heating balance at a low thermal inertia of buildings. The significance of innovative ventilation technologies for raising the energy efficiency has been considered.
\end{abstract}

\section{INTRODUCTION}

Due to the development of market economy also in the real estates and construction, the architects' unconstrained fantasy finds expression in the building of dwelling houses and public houses, offices and trading centres, disregarding the amount of energy to be consumed for heating such constructions.

There are also several ideas about energy-saving buildings, yet they are only on the level of ideas. The new normative acts on heat supply, too, allow rather free interpretation of the thermal endurance of the envelopes of buildings. The new building materials have high thermal resistance but low thermal capacity, which lowers the thermal inertia of buildings. Thermal inertia plays the decisive role in the choice of a heat supply capacity under extreme conditions at low outdoor air temperatures. According to the existing norms, it is sufficient to have a $92 \%$ insurance for the buildings with a great thermal inertia in Latvia in an average perennial year (ensures 5 coldest days), but the buildings with a small inertia require, respectively, a 98\% insurance (ensures 3 coldest days), which determines the choice of the heat supply capacity. However in the buildings of modern architecture, particularly in those the envelope of which is completely or partly made of glass, thermal inertia is much lower, and the heat supply capacity under the Latvian weather conditions must be increased from $10 \%$ up to $27 \%$. Besides, a problematic 
comfort zone arises near such glazed surfaces of buildings where additional ventilation capacities are needed in order to ensure full comfort, which increases the ratio of the ventilation energy in the total consumption of thermal energy for heating. Therefore, in such situations innovative energy-saving ventilation systems are of great importance for the solution of energy efficiency problems. A separate problem is connected with the improvement of normative acts for the calculation of the heat supply of building considering the unlimited possibilities of the modern architecture and the new building materials. The norms existing in Latvia are still connected with the views of traditional construction: historically, starting from massive brick structures, later - precast concrete blocks, and so on. Architects, too, have certain possibilities to take part in tackling the problems how to raise the energy efficiency of buildings by correct orientation of the glazed surfaces in relation to the dominating directions of the impact of the sun, the wind, etc.

In order to ensure such an important energy efficiency improvement in the country, the building normative LBN 002-01 was introduced in 2003, which provided for higher thermal resistances of the envelopes of the newly-built and repaired houses, normative losses of heat and glazing restrictions. Theoretically, the energy efficiency issue of buildings could be settled efficiently because the increased demands for thermal resistance of buildings and the limited optimal glazing, which is $20 \%$ of the floor area of the heated rooms, allows radical cutting of the heat losses. In practice, however, when energy efficient building materials are considered in the projects of houses (3-4 times higher thermal resistances of the envelopes of buildings in contrast to the thermal resistances as fixed in the previous normative), a possibility was seen to interpret rather freely the building normative LBN 002-01 on the issue about increasing the window area. In individual public buildings the envelope is replaced by glazing. In several dwelling houses the window area of some rooms exceeds even $66 \%$ of the floor area, paying insufficient attention to thermal inertia of the building and the comfort problems.

Under such circumstances it becomes of essential importance to economise energy for the ventilation of warm air (in winter) and cold air (in summer). In the same time, at a sufficient cooling extent, a heat supply system can be used if a chillier is installed in the building, which produces the energy of cold from heat. This would raise the efficiency of the heat networks and also the sources of cogenerated heat.

\section{THERMAL INERTIA INDICATORS OF BUILDINGS AND THEIR CHANGES}

In the early 1960-ties, a process of intense building started in Latvia, particularly in Riga. The traditional erection of brick houses was replaced by the fast industrial slab construction, because the rates of the traditional construction could not satisfy the growing demand for the production, dwelling and public buildings. The industrial construction brought into practice the use of the lightweight concrete - aerocrete and claydite-concrete.

The better physical properties of aerocrete - the low unit mass of 600 $800 \mathrm{~kg} / \mathrm{m}^{3}$ for aerocrete as compared with $1100-1200 \mathrm{~kg} / \mathrm{m}^{3}$ for claydite-concrete, and the low heat conductivity of $0.26-0.37 \mathrm{~W} /\left(\mathrm{m}^{2} \cdot{ }^{\circ} \mathrm{C}\right)$ for aerocrete, and respectively, $0.46-0.52 \mathrm{~W} /\left(\mathrm{m}^{2} \cdot{ }^{\circ} \mathrm{C}\right)$ for claydite-concrete, in contrast to the effective 
(perforated) brick wall with its unit mass $1600 \mathrm{~kg} / \mathrm{m}^{3}$ and heat conductivity $0.64 \mathrm{~W} /\left(\mathrm{m}^{2} \cdot{ }^{\circ} \mathrm{C}\right)$, determined the application of aerocrete in making the envelopes of buildings from industrial slabs.

This solution was seen as a promising perspective for the construction of cheap and, at the same time, sufficiently energy-efficient buildings. Technical normalisation of construction was adjusted to the social and economic requirements of that time, and it was also very appropriate for the existing building technologies.

For economic considerations the envelope of the traditional brick houses was built as an effective brick wall, 510-540 mm thick, covered from both sides with a $2 \times 15 \mathrm{~mm}$ thick sand and cement plaster.

The thermal resistance of such a brick envelope is $R_{o}=99\left(\mathrm{~m}^{2} \cdot{ }^{\circ} \mathrm{C}\right) / \mathrm{W}$. The thermal resistance of aerocrete envelope slabs was normalised in the 1960-ties, meeting the demands of the building economy of that time, and was calculated as

$$
R_{o}=n\left(t_{\text {int }}-t_{\text {ext }}\right) /\left(\Delta t^{N} \cdot \alpha_{\text {int }}\right)\left(\mathrm{m}^{2} \cdot{ }^{\circ} \mathrm{C}\right) / \mathrm{W},
$$

where: $n-$ a coefficient that characterises the condition of the envelope in relation to the external environment. For the envelope $n=1$, but for the overhead coverings of upper storeys of the buildings and the buildings with attics $n=0.9$.

$t_{\text {int }}$ - the rated internal (indoor) temperature ${ }^{\circ} \mathrm{C}$ corresponding to the way the room is used (for dwelling houses $t_{\text {int }}=+18^{\circ} \mathrm{C}$ ).

$t_{\text {ext }}$ - the rated external temperature in winter in the geographical position of the building. It is used to determine the thermal resistance of the envelope and is selected depending on the thermal inertia (or massiveness) of the envelope $D$, which characterises the thermal endurance of the envelope and the entire house.

$\Delta t^{N}$ - the normalised temperature difference between the indoor temperature and the temperature on the inner surface of the envelope, which is determined depending on the way the rooms are used. In the living rooms of the dwelling houses $\Delta t^{N}=6^{\circ} \mathrm{C}$.

$\alpha_{\text {int }}-$ the heat conductivity of the inner surface of the envelope equal to $8.7 \mathrm{~W} /\left(\mathrm{m}^{2} \cdot{ }^{\circ} \mathrm{C}\right)(\sim$ const $)$.

The thermal inertia of single-layer envelopes was calculated as

$$
D=R \cdot S,
$$

but for multi-layer envelopes as

$$
D=R_{1} S_{1}+R_{2} S_{2}+\ldots R_{n} S_{n},
$$

where: $R_{1}, R_{2} \ldots R_{n}$ are the thermal resistances $\left(\mathrm{m}^{2} \cdot{ }^{\circ} \mathrm{C}\right) / \mathrm{J}$ of a multi-layer envelope or a building element, a single-layer envelope material or a multi-layer envelope material.

$S_{1}, S_{2} \ldots S_{n}$ are the heat intake coefficients $\mathrm{J} /\left(\mathrm{m}^{2} \cdot{ }^{\circ} \mathrm{C}\right)$ of a single-layer envelope material or a multi-layer envelope material. 
The heat intake coefficient was calculated as

$$
S=0.51 \sqrt{\lambda \cdot C \cdot \gamma}\left(\mathrm{J} /\left(\mathrm{m}^{2} \cdot{ }^{\circ} \mathrm{C}\right)\right)
$$

where: $\lambda-$ the heat conductivity of a layer of the envelope material, $\mathrm{J} /\left(\mathrm{m}^{2} \cdot{ }^{\circ} \mathrm{C}\right)$.

$C$ - the specific thermal capacity of a layer of the envelope material, $\mathrm{J} /\left(\mathrm{kg} \cdot{ }^{\circ} \mathrm{C}\right)$.

$\gamma-$ the specific weight of a layer of the envelope material, $\mathrm{kg} / \mathrm{m}^{3}$.

The rated thermal resistance of the envelopes of the dwelling houses under the climatic conditions of Latvia and, in particular, of Riga was calculated according to formula (1), the rated outdoor temperature being selected depending on the massiveness or thermal inertia of the envelope:

$R_{o}=0.728\left(\mathrm{~m}^{2} \cdot{ }^{\circ} \mathrm{C}\right) / \mathrm{W}-$ for massive envelopes with great thermal inertia, with the numerical value of thermal inertia $D>7$.

$R_{o}=0.785\left(\mathrm{~m}^{2} \cdot{ }^{\circ} \mathrm{C}\right) / \mathrm{W}-$ for the envelopes of medium massiveness, medium thermal inertia, with the numerical value of thermal inertia $4<D \leq 7$.

$R_{o}=0.824\left(\mathrm{~m}^{2} \cdot{ }^{\circ} \mathrm{C}\right) / \mathrm{W}-$ for the envelopes of small massiveness or small thermal inertia, with the numerical value of thermal inertia $D \leq 4$.

Using the already mentioned calculation values, the external (outdoor) rated temperatures $t_{\text {ext }}$ corresponding to the thermal inertia of the envelope, in compliance with the normative of that time for the calculation of $R_{o}$ under the climatic conditions of Riga, were set:

- for massive envelopes of high thermal inertia with the numerical value of thermal inertia $D>7, t_{e x t}=-20^{\circ} \mathrm{C}$, which corresponds to the mean temperature of the coldest 5 days;

- for the envelopes of medium massiveness, medium thermal inertia, with the numerical value of thermal inertia $4<D \leq 7, t_{\text {ext }}=-23{ }^{\circ} \mathrm{C}$, which corresponds to the mean temperature of the coldest 3 days;

- for the envelopes of low massiveness and light weight, with the numerical value of thermal inertia $D \leq 4, t_{e x t}=-25^{\circ} \mathrm{C}$, which corresponds to the mean temperature of the coldest 1 day.

In the calculations of $R_{o}$, lower outdoor rated temperatures but greater temperature differences $t_{i n t}-t_{\text {ext }}$ correspond to lower thermal inertia envelopes, and, hence, greater values of $R_{o}$. In the calculations of thermal inertia $D$, the increased value $R$ of the layer of the envelope material and, hence, also the thickness of the envelope is compensated by the lowered heat intake $S$ of the material with a low specific weight. The increased thermal resistances $R_{o}$ of the envelope at lower values of thermal inertia should be ensured by the heat endurance of the buildings and normal thermal comfort in them when the outdoor temperatures fall in winter below $-20^{\circ} \mathrm{C}$, at which, according to the demands of the normative, the losses of heat in the buildings were calculated and a heating capacity to compensate them was defined.

In reality, the values of thermal inertia of the light-weight concrete claydite-concrete and aerocrete (industrial slabs of the envelopes) $D=3.46$ and 
$D=3.50$ allow relating or qualifying them as envelopes of low massiveness, low weight and low thermal inertia $(D<4)$.

The full calculated thermal resistance of the envelopes from light-weight concrete - claydite-concrete and aerocrete - industrial slabs is correspondingly $R=0.664\left(\mathrm{~m}^{2} \cdot{ }^{\circ} \mathrm{C}\right) / \mathrm{W}$ and $R=0.782\left(\mathrm{~m}^{2} \cdot{ }^{\circ} \mathrm{C}\right) / \mathrm{W}$. It should be stated that the real thermal resistance of the envelopes from light-weight slabs does not meet the demands of, and, by their actual thermal inertia, is even lower than the norm for the envelopes of high thermal inertia. As a result, the buildings with a low thermal inertia and a low rated thermal resistance $R_{o}$ of the envelope have a low thermal endurance. The external temperature $t_{\text {ext }}$ falling below the calculated normalised capacity of the heating systems, the temperature in the buildings starts falling rapidly below the lowest limit of comfort $+18{ }^{\circ} \mathrm{C}$ causing further consequences to the indoor air $-\mathrm{a}$ possible still sharper decrease in the indoor temperature with great losses of heat through the moistened envelopes and still greater possibilities for the water vapour existing in the indoor air to condensate on the internal surface of the envelope, with increased thermal discomfort and decreased energy efficiency of the building.

At that time the thermal inertia of buildings was formally identified with the thermal inertia of the envelope. Before the construction of buildings with the envelopes from light-weight concrete industrial slabs started, houses were basically built with massive brick envelopes and internal walls and with massive reinforced concrete inter-storey coverings. The building elements of the buildings possessed a great heat accumulation capacity and, therefore, a great heat endurance or thermal inertia.

The massiveness and heat endurance of the envelopes from large lightweight industrial slabs was lower and practically corresponded to the indicated rated thermal inertia $D<4$. Therefore, in contrast to the brick houses, these buildings had lower energy efficiency with a worse thermal comfort in them.

These conclusions have by now been confirmed by the 40 -year maintenance of the buildings from light-weight concrete slabs in Latvia.

The severe winter of 1978-79 clearly showed the low heat protection capacities of the large light-weight industrial slabs. In January, at the beginning of the year 1979 and later, the outdoor temperature fell in Riga for two to three days down to $-32{ }^{\circ} \mathrm{C}$, with the mean temperature around the clock being $-26-27{ }^{\circ} \mathrm{C}$. The indoor temperature in the twelve-storey dwelling houses having envelopes from large light-weight concrete slabs decreased even to $10-12{ }^{\circ} \mathrm{C}$, the central heating systems operating to full capacity. The capacity of the heating systems, which had been designed for the outdoor temperature $-20{ }^{\circ} \mathrm{C}$, did not compensate the losses of heat in the buildings, and the low thermal inertia of the buildings could not ensure heat endurance even for 2-3 days of the great cold.

\section{INORDINARY TRENDS IN ARCHITECTURE AND IMPROVEMENT OF ENERGY EFFICIENCY}

In the 1970-ties in the construction of buildings (especially public buildings) a trend appeared to increase the area of the windows, motivating it by both a necessity to increase the distribution of light and raise the architectural expressivity of buildings from large industrial slabs. 
This additionally reduced the already low heat inertia of the houses from large light-weight slabs, the energy efficiency and thermal comfort in them not only in winter but also in summer, because solar radiation through the increased glazing overheated the rooms.

In order to ensure energy saving so needed for the country by raising the energy efficiency of the buildings, the building normative LBN 002-01 "Heat engineering of the envelopes of buildings", which came in force on January 1, 2003, set higher thermal resistances, normative losses of heat and glazing restrictions for the newly-built and renovated buildings.

Formally, the purpose of this new building normative was to achieve the desired energy efficiency and energy saving of buildings. Theoretically, the energy efficiency issue was expected to be resolved effectively, since the increased thermal resistances and the restricted optimal glazing of the envelopes, which was $10 \%$ of the floor area in the heated rooms, allows the losses of heat in the buildings to be reduced dramatically. However in practice this issue is not tackled as it was intended by passing the building normative LBN 002-01.

When perspective energy-efficient building materials were envisaged in the projects of houses, the elements of the envelopes were designed with a particularly high thermal resistance. The high thermal resistances of building envelopes, which are 3-4 times higher than those envisaged in the former normative and ensure 34 times lesser losses of heat in the buildings, were qualified as an indicator of high energy efficiency without paying attention to the thermal inertia of these buildings. Apparently, the high energy efficiency, by identifying it according to the technical resistances of the building envelopes, was seen as an opportunity to interpret freely the normative LBN $002-01$, p. 16 , on the possibilities to increase the area of the windows.

As a result, houses were and are designed and erected with a very increased, even exaggerated glazing, which are not suitable for our weather conditions. In individual public buildings the external walls are sometimes fully glazed. In some new dwelling houses the area of windows in separate rooms exceeds even $66 \%$ of the floor area.

As mentioned above, the energy-efficient building insulation and heat-insulating materials increase the thermal resistance of the envelopes; yet, being of a small volume mass (for example, aerocrete "Aerok" $\gamma=400 \mathrm{~kg} / \mathrm{m}^{3}, \lambda=0.15 \mathrm{~W} /\left(\mathrm{m}^{2} \cdot{ }^{\circ} \mathrm{C}\right.$ ), they do not ensure sufficiently high thermal inertia to produce, in combination with the thermal inertia of glazing, at least medium thermal inertia which, together with the heating system, would be able to maintain the temperature on the comfort level in the buildings for two or three days when the outdoor temperature falls below the rated mean temperature of the coldest five days, which is $-20.7^{\circ} \mathrm{C}$ (in Riga, according to the Latvian building normative LBN 003-01, Tab. 6).

Assuming that the thermal inertia of the building envelope, in accordance with the new building normative LBN 002-01, is indirectly qualified and identified by the volume mass of the envelope $100<\rho<100 \mathrm{~kg} / \mathrm{m}^{2}$, though on condition that the areas of the windows in a house cover $20 \%$ of the heated area of the rooms set by this normative, then formally everything may be all right with the thermal inertia in a building in which the volume mass of the envelope is $\rho>100 \mathrm{~kg} / \mathrm{m}^{2}$, whereas in the buildings with increased glazing and light-weight internal walls or 
planning of the rooms without separating internal walls the identification of the thermal inertia by the thermal inertia of the envelope cannot be considered sufficiently precise. Assuming that the house may have internal walls from lightweight structures with a low thermal inertia but massive inter-storey coverings, the thermal inertia of the very-glazed buildings should be determined as the medium thermal inertia of all - the external and the internal - envelopes:

$$
D_{e}=\frac{D_{1} F_{1}+D_{2} F_{2}+\ldots D_{N} F_{N}}{F_{1}+F_{2}+\ldots F_{N}}
$$

where: $D_{1}, D_{2} \ldots D_{N}$ - the rated thermal inertia of individual envelopes (construction elements) of the building;

$F_{1}, F_{2} \ldots F_{N}$ - the rated areas of individual envelopes (construction elements) of the building $\left(\mathrm{m}^{2}\right)$.

If the thermal inertia of this building is medium $(4<D \leq 7)$ or small $(1.5<D \leq 4)$, then the mean outdoor air temperature of the five coldest days with a $92 \%$ insurance cannot be applied for the calculation of the heat losses in the heating system and its rated capacity. To ensure a building with sufficient heat endurance, the rated outdoor air temperatures could be applied for designing continually operating heating systems in agreement with the Latvian building normative LBN 003-01 "Building climatology", depending on the rated thermal inertia of the building (see Tab.1).

Determination of the rated outdoor air temperature ensuring comfort under extreme conditions

\begin{tabular}{|c|l|}
\hline $\begin{array}{c}\text { The rated thermal } \\
\text { inertia } D \text { of buildings }\end{array}$ & \multicolumn{1}{|c|}{$\begin{array}{c}\text { The rated outdoor air temperature in winter for designing } \\
\text { the heating systems of buildings, } t_{\text {ext }}{ }^{\circ} \mathrm{C}\end{array}$} \\
\hline$D>7$ & $\begin{array}{l}\text { The mean temperature of the five coldest days with a } 92 \% \text { ensuring } \\
\text { (LNB 003-01 Tab. 6). }\end{array}$ \\
\hline $4<D \leq 7$ & $\begin{array}{l}\text { The mean temperature of the five coldest days with a 98\% ensuring } \\
\text { (LNB 003-01 Tab. 6). }\end{array}$ \\
\hline $1.5<D \leq 4$ & $\begin{array}{l}\text { The (arithmetic) mean temperature of the three coldest days with a 98\% } \\
\text { ensuring (LNB 003-01 Tab. 6) and the mean temperature of the coldest } \\
\text { twenty-four hours (in LBN 002-01 defined as the minimal temperature } \\
\text { that can be exceeded once in 10 years, Tab. 2). }\end{array}$ \\
\hline$D \leq 1.5$ & $\begin{array}{l}\text { The mean temperature of the coldest twenty-four hours (in LBN 002-01 } \\
\text { defined as the minimal temperature that can be exceeded once in } \\
10 \text { years, Tab. 2). }\end{array}$ \\
\hline
\end{tabular}

This proposal for applying outdoor temperatures to design continually operating heating and ventilation systems for the provision of buildings with heat agrees with the corresponding reference in the building normative LBN 002-01, p. 54, that the thermal inertia $D$ of a construction element is to be used in the calculations of the capacity of the heating and ventilation systems of buildings in accordance with the Latvian building normative LBN 231-03 "Heating and ventilation of the dwelling and public houses". 
The analysis of the real practice of designing and construction shows that the reference defined in LBN 002-01, p. 54, about the application of the thermal inertia of construction elements of the building or the entire building with possible deviations in order to calculate the capacity of the heating and ventilation systems has a motivation.

Determination of the rated outdoor air temperature in the calculations of the heating capacity of the heating and ventilation systems of buildings depending on the thermal inertia $D$ of the structural elements of the building or the entire building will raise its thermal comfort. Meanwhile one should be aware that the indicated quality of the buildings will be achieved by raising the construction costs of the heating systems in them, because the rated heating capacity of the heating systems will rise when the numerical values of the thermal inertia are $D<7$.

The rated heating capacities of the heating systems, depending on the rated thermal inertia $D$ of the buildings will increase with the rated thermal inertia of the buildings reducing. If the rated capacity of the heating system is assumed as $100 \%$ when the rated thermal inertia of the building $D>7$, then there will be an increase in the heating capacity at other numerical values of the thermal inertia (see Tab. 2).

Table 2

A thermal inertia scale of buildings for the capacity evaluation of the heating system

\begin{tabular}{|c|c|}
\hline $\begin{array}{c}\text { The thermal inertia indicator } D \\
\text { of the building }\end{array}$ & $\begin{array}{c}\text { The capacity of the heating system } \\
(\%)\end{array}$ \\
\hline $\mathrm{D}>7$ & 100 \\
\hline $4<\mathrm{D} \leq 7$ & 110 \\
\hline $1.5<\mathrm{D} \leq 4$ & 119 \\
\hline $\mathrm{D} \leq 1.5$ & 127 \\
\hline
\end{tabular}

This rise in the rated capacities and, hence, the installation costs of the heating systems continually operating in the buildings will increase their thermal comfort, which will promote the regeneration of the working capacity of the population when they are at home and their labour efficiency at work, and decrease their sickness rate during the cold winter months. According to the statistical data published in the technical literature, decrease in labour efficiency of the population is almost proportional to the fall of the outdoor air temperatures. The lower the outdoor air temperature is, the higher the thermal discomfort because of the insufficient heating and thermal inertia of the building.

The thermal comfort can already be qualified as an economic factor which will compensate the rise in the installation costs of the heating systems during the operation of the buildings, increasing the set capacity of the heating systems.

Essential problems can be seen in the houses having low thermal inertia and increased glazing - both in the dwelling and public buildings.

The increased glazing of buildings can be a cause of discomfort and low energy efficiency unless thermal inertia of the envelope is considered and corres- 
ponding energy efficiency measures are taken. The low thermal inertia of the envelope is an important criterion in solving how to remove possible discomfort. Potential consumption of energy, connected with the comfort in the problematic comfort zone near glazed surfaces, should be minimised. Energy efficiency can be raised using modern ventilation systems (with the recuperation and repeated utilisation of heat), considering special air supply, distribution and exhaustion devices.

The temperature on the internal surface of the windows with double glazing and low average thermal resistance of about $0.4\left(\mathrm{~m}^{2} .{ }^{\circ} \mathrm{C}\right) / \mathrm{W}$, which is the most appropriate for the traditional Latvian climate, in winter may fall down to $+6{ }^{\circ} \mathrm{C}$ at the outdoor air temperature being $-20^{\circ} \mathrm{C}$. This is the condensation temperature of the water vapour existing in the air of the room at the room temperature $+18{ }^{\circ} \mathrm{C}$ and relative moisture $45 \%$. To avoid condensation, special heating elements of the heating system are arranged under the windows for their "heating". As a result of this "heating", the air temperature in the window zone of a room rises up to $30^{\circ} \mathrm{C}$, raising the temperature of the internal surface of the windows up to $16^{\circ} \mathrm{C}$, the outdoor air temperature being $-25^{\circ} \mathrm{C}$. Thus condensation is avoided but the losses of heat through the windows increase at least by $30 \%$ and the energy efficiency of the buildings decreases. Consequently, the greater the area of the windows is, the greater the losses of heat through the windows. Without heating the windows and without a possibility of condensation the windows are a cause of thermal discomfort for the people working or being for a long time at a close distance $(\sim 1.0 \mathrm{~m})$ from the windows.

Heat radiation proceeds from the human body, transferring this heat to the cold internal surface of the window. When the temperature difference between the limiting surfaces - the surface of the human body in the clothes and the internal surface of the window glazing - is $20-25^{\circ} \mathrm{C}$, there will be a great radiation transfer from the light clothing of the human body to the cold surface of the window glazing. Radiation heat transfer will increase when this temperature difference increases, i.e., the outdoor air temperature falling, the intensity of radiation heat transfer may reach the freezing effect. Such an effect is fixed in close vicinity $(\sim 1.0 \mathrm{~m})$ to the windows in the rooms of modern glazed office buildings and similar dwelling houses at the outdoor air temperature $-25^{\circ} \mathrm{C}$, and the room temperature $+20^{\circ} \mathrm{C}$.

Introduction of modern rational ventilation systems may essentially increase the energy efficiency and reduce the heat consumption for ventilation, which, in the buildings with large glazed surfaces, may even exceed the energy consumption for heating.

In the rooms of very-glazed edifices the thermal discomfort is felt in summer, too, when the rooms become overheated by the direct solar radiation through the glazing of the windows. On the territory of Latvia, which is situated between 56 and 58 degrees northern latitude, the intensity of solar radiation through the glazing of a house with the façade oriented to the south, southwest and southeast reaches $\sim 145 \mathrm{~W} / \mathrm{m}^{2}$, but with the façade oriented to the east and west - up to $168 \mathrm{~W} / \mathrm{m}^{2}$. Active ventilation is already needed to maintain comfort in the rooms at such an intensity of radiation with the cooling of the air supplied to the rooms and the 
consumption of electric energy, reducing the energy efficiency of the building also in summer. In the overheated rooms of excessively glazed offices and dwelling houses the consumption of electric energy to cool the rooms in order to maintain normal thermal comfort exceeds $100 \mathrm{~W} / \mathrm{m}^{2}$ per hour, which is a potential for energy saving and for the development of a rational ventilation system.

\section{CONCLUSION}

The creative power of architects is unlimited, and it should be attracted to raising energy efficiency of buildings, their heat supply, ventilation and cooling, in order to achieve the maximum comfort with the minimum consumption of energy. It is hard to prognosticate the constructive development and design of the buildings created by modern architects; however the simplest ways would be: up-to-date blinds, orientation of the glazed surfaces of houses to the cardinal points, modern barriers and structures for deflection of the dominating winds away from the glazed surfaces in order to reduce their cooling in winder and increase it in summer, etc.

\section{REFERENCES}

1. Petrovs, B., Puikevica-Puikevska, I., Zeltins, N. (2003). Evaluation of potential possibility of energy efficiency in dwelling. Proceedings: Healthy Buildings (Singapore), pp. 675-680.

2. Ekmanis, Yu., Michna, J., Stania, A. \& Zeltins, N. (2004). Uncertainty in energy conservation policy. Foundation for Energy and Environmental Policy, 6 Wolności , 41-700 Ruda Śląska, Poland, ISSN 0867-2172, ZESZYT NR 4/2004:38 p.

3. Melko, A., Zebergs, V. \& Zeltins, N. (2004). Energy efficiency managing problems in post-transition countries. Proceedings of 3rd European Congress on Economics and Management of Energy in Industry, Lisbon (Portugal), CD.

4. Mikelsons, K., Kreslinsh, V., Brinkis, K., Zebergs, V. \& Zeltins, N. (2005). Energy Efficiency and Renewable Energy Problems in the New EU Countries. The 25 $5^{\text {th }}$ annual North American Conference of IAEE/USAEE, Omni Interlocken Resort, Denver CO USA, CD.

5. Frormann, D., Michna, J., Stania, A., Ekmanis, J., Zebergs, V. \& Zeltins, N. (2006). Present-day problems of energy conservation policy in Central and East-European countries. Latv. J. Phys .Tech. Sci. (5), 68-76.

6. Vrublevskis, V., Zebergs, V., Zeltins, N. \& Puikevica-Puikevska, I. (2007). Additional energy saving in a building with improved insulation. Latv. J. Phys .Tech. Sci. (2), 32 40.

7. Zebergs, V. Zeltins, N., Krams, Z., Silantjeva, I. \& Grackova, L. (2007). Dependence of energy efficiency and GG emissions on the energy structure and fluctuations in consumption Latv. J. Phys.Tech. Sci. 3 3-14.

8. Ekmanis Yu., Zebergs, V. Zeltins, N., Silantjeva, I. \& Grackova, L. (2007). Management of the energy efficiency process. $4^{\text {th }}$ European Congress on Economics and Management of Energy in Industry, Porto (Portugal), CD.

9. Ney, R., Michna, J., Ekmanis, Yu., Zeltins, N. \& Zebergs, V. (2008). Energy use and related risk management problems in CEE countries. Latv. J. Phys. Tech. Sci., 45 (1), 41-51.

10. Latvijas Republikas Pirmais energoefektivitātes rīcības plāns 2008.-2010.gadam. Izskatīts MK 13.05.2008, 30\#20 


\section{JAUNO BŪVMATERIĀLU TERMISKĀS ĪPAŠĪBAS UN TO IETEKME UZ ENERĢIJAS EFEKTIVITĀTI}

J. Ekmanis, V. Zēbergs, N. Zeltiņš, V. Vrubḷevskis

Kopsavilkums

Darbā formulēta būvmateriālu siltuminerces loma ēku energoapgādes un energoefektivitātes problēmu risināšanā. Būvniecības attīstības saistīta ar jaunu būvmateriālu pielietošanu, kā arī ar palielinātu stikloto virsmu ieviešanu ēku ārējo konstrukciju veidošanā. Analizēti būvmateriālu termiskās pretestības un siltuma ietilpības iespaids uz ēku siltuminerces indikatoriem. Izstrādāta ēku inerces skala ēku siltumapgādes jaudu izvēlei ekstremālos apstākḷ os pie zemām ārgaisa temperatūrām Latvijas klimatiskajos apstākḷos. Analizēts ventilācijas jaudu īpatsvars kopējās apkures jaudās pie ēku zemes siltuma inerces. Izvērtêts nozīmīgums enerğijas efektivitātes paaugstināšanā inovatīvām ventilācijas tehnologijām.

02.06.2008. 